\title{
The Efforts to Reduce Academic Procrastination of Fifth Grade Students on Elementary School
}

\author{
Ratih Dewi Puspitasari *, Suwarjo Suwarjo \\ Department of Primary Education, Program Pascasarjana, Universitas Negeri Yogyakarta. \\ Jalan Colombo No. 1, Karangmalang, Yogyakarta, 55281, Indonesia. \\ *Corresponding Author. Email: ratih.dewi2016@student.uny.ac.id \\ Received: 10 July 2018; Revised: 9 August 2018; Accepted: 10 October 2018
}

\begin{abstract}
The learning process of students must be accompanied by a diligent attitude, discipline, and obedience, so that they can be optimal. Time management of learning became one of the problems that will have effect to students. An effect of time management is the phenomenon of students' tendency to postpone academic assignments. The performance of students who postpone completing a task might not maximize the student academic achievement. Academic procrastination is a situation where the students do not want to try to complete the task in the period of time as expected. This study described various efforts by the teacher to reduce the student academic procrastination. The type of research was descriptive research using qualitative descriptive approaches and case study methods. The subjects were grade $\mathrm{V}$ teachers who had efforts to overcome the academic procrastination. Data collection techniques were interviews, observation and documentation. The analysis technique was interactive analysis which has three components, namely (1) data reduction, (2) data presentation, and (3) verification. The findings showed that the efforts made by the teacher to reduce students' academic procrastination are by schedule of daily activities, diary, motivation, achievement tables and good communication between teachers and parents.
\end{abstract}

Keywords: academic, procrastination elementary school students

How to Cite: Puspitasari, R., \& Suwarjo, S. (2018). The efforts to reduce the academic procrastination of students on grade V elementary school. Jurnal Prima Edukasia, 6(2), 189-195. doi:https://doi.org/10.21831/jpe.v6i2.20293

Permalink/DOI: https://doi.org/10.21831/jpe.v6i2.20293

\section{Introduction}

The primary task for the student is learning. The learning process is a process where someone taught to be diligent and obedience, to create a transfer of knowledge, mastery of capability and character, attitude establishment and trust in the student. It is undertaken by the student with a good learning time management. Time management is required by the student to organize a proper learning design, both in assignments and discipline and measured learning process. Discipline is highly needed to make a decent learning process.

Time management becomes one of the problems will create domino effect to the students or university students. Domino effect of time management includes the students do procrastination like deferment to submit assignments, going to school on time, and coming into the class after the bell rings immediately. Students should have positive attitude and academic behavior that can support the achievement of educational goals. An ideal learning behavior can be created if the students are conscious of their responsibility as students so that they can manage their time between learning and activities besides learning.

The phenomenon among students is a tendency of students to do procrastination to the academic assignment. Gallagher, Golin, \& Kelleher (1992, p.319) show 52\% students stated that they had a problem with procrastination. A similar study carried out by Balkis \& Duru (2009, p.6), the study showed that the lower age the more procrastination increase, and the other way around. It revealed that procrastination at primary school age was higher.

According to McCloskey (2012), Procrastination comes from Latin "pro" which means going forward and "crastinus" means tomorrow. Procrastination can be interpreted as the behavior of delaying activities. Procrastination means behavior of putting off the activities consciously 
even though knowing it has negative consequences (Klingsieck, 2013, p.32). Procrastination means as the behavior of postponing something up to the next day. Academic procrastination is a procrastination that occurs in the academic field. Procrastination is doing postponement toward something that should be done (Zakeri, Esfahani, \& Razmjoee, 2013, p.57). In line with Şirin (2011, p.448) that academic procrastination happens on the academic tasks adjournment for some reasons. This tendency could be without excuse, or probably with good intentions but not realized. Academic procrastination in students committed mindfully on assignments. Students who delay in completing the assignments cannot be maximizing academic achievement. Nevertheless, students still like to postpone completing the tasks. It is a condition where the students do not want to complete assignments within the time as expected.

Procrastination that occurs continuously will give a deficient impact on the future. Students are not productive and have an ineffective performance so that the goals cannot be attained. According to Thakkar (2009, p.2), academic procrastination is an irrational condition where students consciously chose an action not to maximize performance they know it is bad for psychology and prosperity of their future. Therefore, it is a common problem among students and reacting to the students' personality, psychology, and academic achievement.

Academic procrastination consists of six areas: (1) Writing Assignment, it is procrastination in composing or other writing assignments, (2) Learning Assignment, it is procrastination of obligation about school assignment or facing school examination, (3) Reading assignment, comprises the procrastination reading books related to the academic, (4) Administrative assignment, includes copying or completing terms related to the school, (5) Attending academic forum, it is procrastination or retardation of going to school or learning process 6) Academic performance, on the whole, postponing the obligation of accomplishing academic assignments entirety (Solomon \& Rothblum, 1994). Academic procrastination that occurs to the students in the primary school generally involves learning task, retardation of going to school and academic performance.

Aspects of academic procrastination in solving school assignment based on Milgram, Sroloff, \& Rosenbaum (1988, p.75) stated that in procrastination consists of four aspects, among others: (1) Implicating the element of procrastination, both for starting and completing assignments. Procrastinator students tend not to start immediately doing the assignment until the finish. (2) Obtaining other consequences even further, like retardation of resolving assignment or failure in doing the assignment. The student who has the propensity to put off solving school assignment causing the student in haste to do that then the result is not maximal. (3) Involving an assignment perceived by the procrastinator as an important task to do, that is school assignment. The student knows it is significant but not to solve it right away and even doing an unimportant task. And (4) creating emotional situation which is not pleased, like uneasy, guilty, angry and panic feeling.

Some causes or factors of academic procrastination according to Burka and Yuen (2008, p.11) are influenced by self-concept, selfconfidence, responsibility, restlessness about evaluations that will be given, difficulty in making a decision, insurrection against control figure who provide authority, an exorbitant standard for individual and lack of task demands. In line with Spillane (2003, p.112) that inclination of procrastination comes from: (1) Fear of failure because the goal is not realistic, (2) fear of fruitfulness that gives a consequence of additional responsibility, (3) expression of rejection or rebellion, (4) lack of ability to solve the problem, and (5) perfectionist attitude (demanding perfection). Accordingly, the causes of procrastination are fear of failure, dislike of assignment and some other factors previously mentioned.

Academic procrastination applies to all humans and does not consider the age, gender, student or not student (Burka \& Yuen, 2008, p.4). Thus, the academic procrastination also occurs to the primary school students. Students of primary school need more attention to this. It can be said that procrastination is not efficient in time management and should be removed, if the behavior is left alone it will reduce productivity and get an adverse impact to the personality. Procrastination that occurs continuously will make student has the attitude pattern to adulthood.

Primary school age is the right time to building the character and continues to a higher level (Masnur, 2017, p.80). Building attitude, behavior, habit, and character is in the primary school. Behavior is a part of the character component. If someone has a good character, the 
Jurnal Prima Edukasia, 6 (2), July 2018 -191

Ratih Dewi Puspitasari, Suwarjo Suwarjo

behavior will follow it, and the other way around. $\mathrm{Bad}$ behavior must be corrected and directed from an early age. Lickona (2013, p.52) stated that when a child has poor behavior, that child needs the right feedback and as soon as possible. The research about procrastination is infrequently held to the primary school students.

Muhi (2011, p.7) stated that the education in the rural area gives a little knowledge, skill, and decent ideas in order to work efficiently in the rural environment (agriculture, health, healthy and nutritious food, community development and so on). According to Wahyono, (2012, p.12) urban people have more ability to survive in social-economic competition, so that they have world perspective more progressive and inclination to move higher. Because of this, time management at an urban area is possibly better from the rural area. Student characteristic, education, and environment that support the reduction of academic procrastination must be different between urban and rural area. However, the dissimilar condition also found at one of the primary schools in Kulon Progo. 80\% of the fifth grade students did not refer to the procrastination. It was because the teacher had some efforts to reduce procrastination. The aim of this study was to describe deeply the efforts in reducing academic procrastination of fifth-grade students of the rural primary school in KulonProgo, Yogyakarta. In this study, the researcher used case study to reveal on how the teacher's efforts to reduce academic procrastination of fifth-grade students. The objectives of this study were (1) what efforts have been made by the teacher in reducing academic procrastination of student? (2) How are the efforts to reduce academic procrastination of student?

\section{Method}

This research used qualitative research as an approach. This approach directed to the individual background. In this case, it may not isolate individual or organization into variable or hypothesis, but consider it as a part of integrity. This research used qualitative descriptive. Qualitative descriptive research is research with case study method. This study focused intensively on one certain object and learns it as a case. The determination of this method based on the fact that this study is unique, that is academic procrastination at primary school student which is rarely appointed in research and teacher who has efforts in reducing academic procrastination of primary school students. Besides that (Pychyl
\& Flett, 2012, p.210), although the impact of academic procrastination which is bad for students high enough, not many and rare research about the intervention of academic procrastination treatment.

The subject in this research was taken by choosing subject and informant based on criteria determined by the researcher. It selected through purposive (based on certain criteria), and found the subject appropriate with the theme of research. The main subject was teacher of fifthgrade of primary school in Kulon Progo. The stipulation of subject was because the teacher had efforts that could reduce academic procrastination of student. Teacher managed academic procrastination successfully. Students in rural area had defective procrastination, but through the efforts implemented by the teacher, it could reduce academic procrastination of student. Secondary subjects were fifth-grade student and the principal. The students were handled by the main subject. This study conducted from September to December.

This study needed a number of data in the field. It collected the main data and additional data at once. "Main data source in qualitative research is words and action, while written data, photos, and statistic are the secondary data" (Moleong, 2007, p.157). Data collection technique is the strategic steps in a research. By using data collection technique correctly, the researcher will obtain data met with the standard. The followings are data collection techniques used in this study:

\section{Data Collection by Observation}

The researcher did a participative observation to obtain data. The participative observation was applied in the passive participation group and forthright observation. The observation was held in fifth-grade classroom of the elementary school in KuluwaruKulon. It was implemented gradually in one month, exactly in October and November. The observation result was recorded on an observation sheet arranged by the researcher.

\section{Data Collection by Interview}

Mostly data was obtained by interview; the researcher would know a profound thing about the participant and interpret the situation and phenomenon, where it could not be found by observation. The interview was intended to the teacher, students, and principal. It was interviewed in the classroom at recess or free time of 
Jurnal Prima Edukasia, 6 (2), July 2018 -192

Ratih Dewi Puspitasari, Suwarjo Suwarjo

teacher, students, or principal. The result of the interview was findings recorded on the interview sheet and presented as data in this research.

\section{Data Collection by Document (Document Study)}

Documentation technique in qualitative research is a complement of observation and interview. The document could as the lesson plan, photos, picture, student diary, student's daily schedule, video, etc.

The main instrument of qualitative research is the researcher (human instrument). The human instrument needs proponent instrument as a tool to collect data in order to make it intended. The secondary instruments in this study were interview guidelines, observation sheet, and documentation. The study used a triangulation technique to test the validity of the data with the result that appropriate to the objective and purpose of the study. It was applied method triangulation and source triangulation. Method triangulation was taken by checking to the result of the study that was collected by interview, observation, and documentation. Source traingulation was taken by checking to the result of the study at teacher, students, and principal.

Analysis technique was interactive analysis (Miles, Huberman, \& Saldana, 2014, p.12). This model of analysis has three components namely data reduction, data display, and conclusion drawing (verification).

\section{Result and Discussion}

These are the result of the interview, observation, and documentation with the teacher, students, and principal on the efforts to reduce academic procrastination of fifth-grade students of the elementary school. And then, the researcher describes the efforts as follows.

Teacher obligated the students to schedule daily home activities. The students made their daily schedule at school. The daily activities schedule was made by the guidance of teacher or parents. The activity started from wake up, ready to go to school, the learning process in the classroom all day, including extracurricular, tutoring, praying, playing, and so on. Teacher guided to make learning activity and others going wellbalanced. Students put the schedule sheet in their bedroom. The teacher asked them to have responsibility for managing their activity on the track. Students were given trust to control the time and responsible according to consciousness.

The teacher asked the students to make a diary that is not too personal. Contents of the diary were about activities, feeling and condition that only student and teacher knew. The diary was collected every last hour of the lesson at school. The teacher gave responses or reaction in it. If they meet problem, the teacher helped and suggested a solution. Students could express the emotional feeling related to friendship, family, and difficulties in academic or non-academic life. Moreover, the students wrote about the health condition and so forth. Teacher needed to understand students' emotional condition and problems. Teacher delivered the best responses and reaction to every student's matter. Diary was returned the next day. It happened every day. The good relationship appeared from good communication between teacher and students. Even students conveyed directly the favorite task or difficult assignments in the diary. So, it could be used by the teacher to evaluate the learning process.

The teacher used to give motivation. Every material was constantly associated with the motivation and advice. Besides that, motivation was offered an opening activity. The teacher played motivational video routinely once a week or two. The teacher also told fairy story to motivate students. The teacher delivered a speech that could be found based on the video or the story. However, students sometimes requested to get their own message from the video or story. The story was loved by the students. The teacher believed that every human has different potency. The teacher realized to develop the potency is teacher's job.

The teacher made the students' achievement list. The list contained students' name and stars as a mark of work assignments. Students who did the task in discipline would get a star. Students competed to receive stars.

Another effort by the teacher is a proper communication between teacher and parents. The teacher realized that the parents contributed a lot to reduce procrastination. The student who got full attention from parents would have a spirit to learn and discipline to complete the task. If there was a student had problems related to the parents' involvement so that student could not learn well, the teacher needed to discuss or communicate with the parents.

Another finding in this study was teacher served assignments by the interesting way. Such as different group making, task presentation, giving task by using environment and family. The teacher used to use captivating way like forming a different group every day. The teacher also 
provided the assignments well, as connected to the students' favorite reading material, favorite activity, and other creativity developments. For instance, the teacher wanted the students to write poetry about the family by using folding paper and made as for its creativity.

Sometimes teacher utilized environment as homework like making eco-brick and lanterns from used goods and so on. The assignment also needed to do by the complicity of parents like interviewing parents, entrepreneurship with parents, or other activities with parents. The teacher always tried not to make it hard. The task framing used to be liked by students. Students perceived having interesting, challenging, and not the intrusive task.

Figure 1 is the figure of the discussion about research findings.

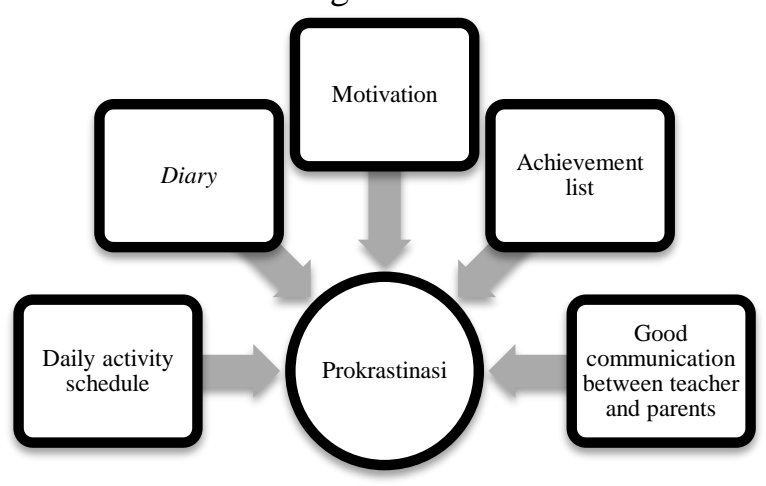

Figure 1. The Efforts to Reduce Academic Procrastination of the Students.

Daily activity schedule would train students to be discipline and managing the time well. Students needed to utilize time so that they do not have an unnecessary activity to do. Nasrullah and Khan (2015, p.66) stated that good time management will affect the students' performance to be conducive. However, time management of daily activity should be managed properly. In consequence, routine time management must be managed in a balanced manner so the bad effect would not appear like stressed out. Activity conducted by the teacher aiming to make students no to spend the time a lot to learn and feel burnout or exhausted. Students also did not spend the time only for playing. Free time would be used nicely through daily activity schedule. Students were invited to be discipline to obey the schedule they made. So, the disciple would reduce procrastination in completing the school task. This would reduce or remove the academic procrastination of the student.

Students who are accustomed write diary would know their own life. They could interpret life better. Students as a human would always have an emotional condition or physically that is not similar. Students sometimes find some obstacles and condition that should be understood. So, when procrastination happened teacher does not necessarily blame the students or punish them. But through the diary, the teacher could know why the students did it. A wise teacher does not judge the students' mistake, but the teacher knows very well how the condition of the students' behavior. Yunus, Osman, \& Ishak (2011, pp. 26-37) revealed that teacher needs to understand that students come from different culture and background that is worthy to be respected as an individual. Moreover, their necessity is dissimilar each other. The teacher needs to be aware of the importance of building closeness between teacher and students. Through the positive closeness will give a chance to students having good learning motivation.

Diary juxtaposes relationship between teacher and students warmly. The teacher and students could have a connection like a friend that can understand and give solution on every problem. Reactions and responses given by the teacher in the diary were positive reinforcement, negative, advice/suggestion and also solution if the students need. Some students are lazy and postponing school task because of emotional condition or problems. The problems must be overcome to make students still focused and excited to complete the task. If the teacher helps the students to fix it, it will not be continuous, and students get back to the activity in academic life nicely. If the students are diligent or do something right, the teacher always gives positive reinforcement in it.

Teacher's motivation is necessary to make students are not lazy to learn. The teacher always gives motivation to make the students diligent and complete the task. According to Riswanto \& Aryani (2017, p.43), motivation could play a role in how many students will learn. Motivated students feel comfortable and enthusiastic. It could reduce the procrastination. Procrastination could be demoted by the motivation to escalate the students' spirit. Learning motivation is needed to raise students' enthusiasm in completing the assignment. Habiby \& Wangid (2013, p.219) stated that good motivation will influence students to complete the academic task with a pleasant feeling. Students who have high spirit will not do procrastination. Motivation will impress emotion and behavior so that procrastination will be reduced. If students have low 
Jurnal Prima Edukasia, 6 (2), July 2018 -194

Ratih Dewi Puspitasari, Suwarjo Suwarjo

motivation in learning and do not have a spirit to complete the assignment, the procrastination will be followed.

Positive reinforcement is necessary to build up students' discipline. The teacher is demanded to be able to present positive reinforcement with delight method at elementary school. Table board is one of the ways to give positive reinforcement to the students. Stars are given to put students in control to complete the assignment. Students who get the star will be motivated to obtain stars anymore. The students, who did not get the star, will be motivated to get the star. The discipline needs to be appreciated well by the teacher to increase the discipline of students. It will be reduced and deprived the procrastination. Kelly \& Pohl (2018, p.27) stated that modifycation in positive reinforcement is more effective rather than punishment. Hence, good positive reinforcement will reduce academic procrastination and improve the students' interest. Using star the table procedure will manage the students to behave well. The building of discipline with proper method applied to reach meaningful learning. Punishment is not allowed in this management.

School education is nor apart from the education of the home environment. Parents hold a significant role to develop good students' character. Parents' role to encourage and control students in activities will avoid students to do procrastination. Parents need to involve in reducing academic procrastination of students. Students who take the surveillance and encouragement from parents will always complete the academic task and learn. Discipline is also as a form of upbringing from parents. Teacher needs to get back up from parents so the efforts of reducing procrastination achieved. Fasina (2011, p. 43) pointed that the entanglement of parents is very crucial in the elementary school age education and it has several advantages such as (1) Expanding children's thinking horizon, (2) intensifying social relationship, and (3) promoting self-concept and self-efficacy. Students can learn the character discipline in time management from parents' education at home. Good relation between teacher, students, and parents will create self-confidence and self-respect to strive for a good academic discipline manner. When students are in high self-confidence, the students can be always discipline. And, the academic procrastination is also low. In the last, the efforts to reduce academic procrastination can be established through the cooperation among parents, teacher, and students.
Another finding also appeared in this study. The teacher presented the assignment interestingly. The teacher provided assignment interestingly and produced a creative task. One of factors that caused students had academic procrastination is a dislike perspective of the task. This feeling obtained from the negative perspective about the task. Students found the task was too much, unhappy and unsatisfied. Several students had low procrastination because the students did not like the task. Meanwhile, in this finding, the teacher presented the task well. It was started from the format of task to the way of giving the task. The student did not feel indisposed and difficult to complete. As a result, the task could make students like the task and low on procrastination.

\section{Conclusion}

This study represented the result that the efforts applied by the teacher to reduce academic procrastination of students were by making daily activity schedule, diary, motivation, achievement table, and good communication between teacher and parents. Daily activity schedule contained activities in daily life of students. Daily activity schedule was used as reference to control the students time every day. Diary would give the emotional description and students' problems, so the problem could be handled. The teacher used to give motivation to the students to avoid the academic procrastination. The students' achievement table was the tool used by the teacher to appreciate the students. Good communication between teacher and parents was needed so that parents would encourage and know the students' activity

\section{References}

Balkis, M \& Duru, E. (2009). Prevalence of academic procarastination behavior among pre-service teachers, and its relationship with demographic and individual preference. Journal of Theory and Practice in Education. 5(1), 18-32

Burka, J. B., \& Yuen, L. M. (2008). Procrastination: Why you do it, what to do about it now. Hachette UK.

Gallagher, R. P., Golin, A., \& Kelleher, K. (1992). The personal, career, and learning skills needs of college students. Journal of College Student Development, 33(4), 301310

Habiby, W., \& Wangid, M. (2013). Efektivitas 


\section{Jurnal Prima Edukasia, 6 (2), July 2018 -195}

Ratih Dewi Puspitasari, Suwarjo Suwarjo

pelatihan motivasi untuk menurunkan tingkat stres siswa dalam menghadapi ujian nasional sekolah dasar. Jurnal Prima Edukasia, $\quad$ 1(2), 208-221. doi:https://doi.org/10.21831/jpe.v1i2.2637

Klingsieck, K. B. (2013). Procrastination: When good things don't come to those who wait. European Psychologist, 18(1), 24-34. http://dx.doi.org/10.1027/10169040/a000138

Kelly, J., \& Pohl, B. (2018). Using structured positive and negative reinforcement to change student behavior in educational settings in order to achieve student academic success. Multidisciplinary Journal for Education, Social and Technological Sciences 5(1). 17-29. https://doi.org/10.4995/muse.2018.6370

Lickona, T. (2013). Pendidikan karakter: Panduan lengkap mendidik siswa menjadi pintar dan baik. Bandung: Nusa Media.

Masnur, M. (2017). Pengaruh SSP tematik terhadap peningkatkan karakter kejujuran dan disiplin peserta didik kelas I SD. Jurnal Prima Edukasia, 5(1), 79-90. doi:https://doi.org/10.21831/jpe.v5i1.7745

McCloskey, J. (2012). Academic Procrastination: the development of a scale. Lambert Academic Publishing.

Milgram, N. A., Sroloff, B., \& Rosenbaum, M. (1988). The procrastination of everyday life. Journal of Research in Personality, 22(2), 197-212.

Miles, M. B., Huberman, A. M., \& Saldana, J. (2014). Qualitative data analysis. Sage.

Moleong, L. J. (2007). Qualitative research methodology. Bandung, PT Remaja Rosdakarya.

Muhi, A. H. (2011). Problema pendidikan di pedesaan. Jatinagor: Institut Pemerintahan Dalam Negeri

Nasrullah, S., \& Khan, M.S. (2015).The impact of time management on the students' academic achievements. Journal of Literature, Languages and Linguistics, 11, 66-71.

Pychyl, T. A., \& Flett, G. L. (2012). Procrastination and self-regulatory failure:
An introduction to the special issue. Journal of Rational-Emotive \& CognitiveBehavior Therapy, 30(4), 203-212. https://doi.org/10.1007/s10942-012-01495

Riswanto, A., \& Aryani, S. (2017). Learning motivation and student achievement: Description analysis and relationships both. COUNS-EDU: The International Journal of Counseling and Education, 2(1), https://doi.org/10.23916/002017026010

Şirin, E. F. (2011). Academic procrastination among undergraduates attending school of physical education and sports: Role of general procrastination, academic motivation and academic self-efficacy. Educational Research and Reviews, 6(5), 447-455.

Solomon, L. J., \& Rothblum, E. (1994). Procrastination assessment scale-students (pass). Measure for Clinical Practice, 2, 446-452.

Spillane, S. J. (2003). Time management, pedoman praktis pengelolaan waktu. Yogyakarta: Kanisius.

Thakkar, N. (2009). Why procrastinate: An investigation of the root causes behind procrastination. Lethbridge Undergraduate Research Journal (LURJ). Retrieved from https://opus.uleth.ca/handle/10133/1241

Wahyono, S. B. (2012). Transformasi kultural menuju demokrasi substansial. Jurnal Pemikiran Sosiologi, 1(1), 16-29.

Yunus, M. M., Osman, W. S. W., \& Ishak, N. M. (2011). Teacher-student relationship factor affecting motivation and academic achievement in ESL classroom. Procedia Social and Behavioral Sciences, 15, 26372641.

https://doi.org/10.1016/J.SBSPRO.2011.0 4.161

Zakeri, H., Esfahani, B. N., \& Razmjoee, M. (2013). Parenting styles and academic procrastination. Procedia - Social and Behavioral Sciences, 84, 57-60. https://doi.org/10.1016/J.SBSPRO.2013.0 6.509 